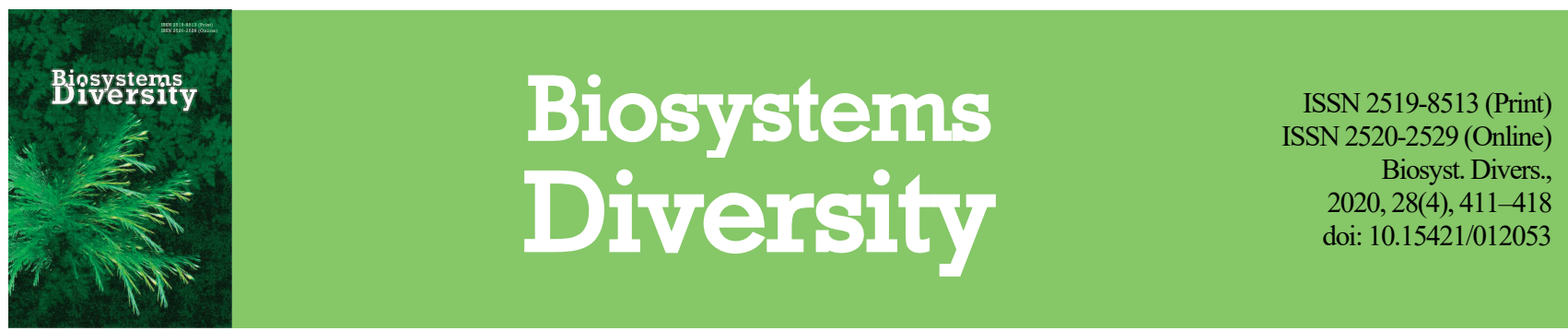

\title{
Mode of physiological activity of acylcyclohexadione retardants
}

\author{
L. M. Mykhalska, T. M. Makoveychuk, V. V. Schwartau \\ Institute of Plant Physiology and Genetics, National Academy of Sciences of Ukraine, Kyiv, Ukraine
}

Article info

Received 22.10.2020

Received in revised form 15.11 .2020

Accepted 16.11.2020

Institute of Plant Physiology and Genetics, National Academy of Sciences

of Ukraine, Vasylkivska st.,

31/17, Kyiv, 03022, Ukraine.

Tel.: +38-044-257-90-18.

E-mail:

VictorSchwartau@gmail.com

\author{
Mykhalska, L. M., Makoveychuk, T. M., \& Schwartau, V. V. (2020). Mode of physiological activity of acylcyclohexadione retar- \\ dants. Biosystems Diversity, 28(4), 411-418. doi:10.15421/012053
}

The key to high productivity of plants, especially cereals, is to control lodging of cereals. Among the derivatives of acylcyclohexadiones (ACHD), highly effective retardants have been invented, which are widely used in modern crop production to control the lodging of cereals, mainly winter wheat, spring and winter wheat, winter, spring and hybrids of barley. The mechanisms of influence of ACHD derivatives - trinexapac-ethyl and prohexadione-Ca on plants and features of their application in technologies of cultivation of cultivated plants are considered. By using a composition of ACHD derivatives with a number of agrochemicals, enhancement of retardant activity is achieved. Given the identified varietal variability of the effectiveness of the use of ACHD derivatives in cereals, it is advisable to conduct registration and post-registration studies primarily on varieties that occupy the largest sown areas in the country. The peculiarities of ACHD derivatives' influence on stem components as the main one, along with the flag leaf, carbon pool for grain filling in the ear and possible reasons for the lack of productivity increase of grain crops due to ACHD derivatives are also considered. This class of substances continues to be widely studied in the world and remains among the most promising for the development of new agrochemicals and drugs.

Keywords: lodging; PGR; trinexapac-ethyl; prohexadione-Ca; calcium metabolism; productivity; cereals.

\section{Introduction}

The "Green Revolution" has significantly increased the yields of cereals in the world. Increase in the production of high-quality grain is an important trend in the development of crop production and increases its profitability (Morgun et al., 2010, 2015; Reynolds, 2012; Pinera-Chaves et al., 2020). An important element of wheat cultivation technologies is the prevention of lodging, which significantly reduces crop productivity and grain quality. On high nutrition backgrounds, with the application of nitrogen fertilizers, especially in combination with waterlogging and low insolation, the wheat stalk may stretch and lose strength. Crops are also affected by weeds and fungal damage to stems and roots. Therefore, an important condition for increasing the productivity of winter wheat is to counteract lodging, including short-stem varieties in crops with a yield of 7-9 tha and more. This can be achieved through selection of varieties and with the help of growth regulators. With increasing doses of nitrogen fertilizers for high-yielding short-stemmed and medium-growing varieties of cereals, the use of retardants to combat crop lodging is part of crop production technologies (Berry, 2004; Espindula, 2009; Morgun, 2010; Miroshnichenko et al., 2017). Lying down occurs by breaking the internodes of the basal part of the stem, the displacement of the plant from a vertical position at an angle to the soil surface, under the influence of various factors. To reduce lodging susceptibility and increase yields, it is important to introduce dwarf alleles into the main crops, as semi-dwarf plant varieties have a thicker wall and a larger stem diameter, which helps to solve lodging problems and increase yields (Morgun et al., 2010; PiñeraChavez et al., 2020). Identification of dwarfism genes has shown that encoded proteins inhibit the action or production of GA (Hedden, 2003). But if the height of the plants is too short, the yield decreases. The resistance of plants to lodging depends not only on the length but also on the structure of the stem. Exogenous use of growth inhibitors to reduce internode length and reduce lodging affects the endogenous content of hormones, which play an important role in increasing plant productivity and stem resistance to lodging (Berry \& Spink, 2012). Growth inhibitors are now widely used to control plant height and prevent crop lodging. Their use also helps to mitigate the effects of adverse environmental conditions that lead to lower yields. They alter metabolism by controlling hormonal status and thus regulating the growth of various plant organs.

Ukraine has traditionally conducted research to create a new generation of PGR (synthetic and natural), including primary screening of these substances, research on their physicochemical, physiological and toxicological properties and implementation results in agricultural production. Analysis of literature data on the use of PGR of synthetic and natural origin indicates the viability of this technological measure in agriculture. The number of PGRs registered in Ukraine, which currently exceeded 100 items, rather indicates methodological inaccuracies. Thus, in the laboratory, a large number of organic and inorganic compounds on unbuffered growth media with low osmotic pressure exhibit the properties of PGR, mainly effective stimulants, but this effect is not reproduced in field production conditions. The lack of reproducibility of many stimulants in the field which researchers try to position as PGR is due to the complexity of the processes of regulating the growth and development of plants in ontogenesis, where the action of one substance in ultra-low concentrations is compensated. For example, many years of experience in large-scale production and use of gibberellic acid in the former USSR did not lead to increased yields.

Problems with the use of retardants on the Ukrainian market are persistent recommendations to prohibit the introduction of retardants - acylcyclohexadione (ACHD) at night, the lack of restrictions on their application in arid conditions, which indicates insufficient justification of these recommendations. It should also be mentioned that the world's leading pesticide companies, which together spend tens of millions of dollars a day on research, have registered only a few retardants in Ukraine and detailed recommendations for their use. Among the innovative drugs should be noted retardants of the class of ACHD derivatives.

Retardants - synthetic growth and development regulators of inhibitory type with antigibberelin mechanism of action, blocking the synthesis or physiological action of synthesized gibberellin, are able to slow plant growth, usually without causing phytotoxicity (Sang-Kuk \& Hak-Yoon, 2014; Rademacher, 2016). Retardants are a large group of chemical compounds of different structures, united by common genetic, physiological and morphological effects and mode of action. These substances are able 
to affect the morphogenesis of plants (Altintas, 2011; Yang et al., 2016; Kuryata \& Shataliuk, 2020), regulation of growth processes, by shortening and thickening the stem, reducing the tendency to lodging, to enhance root growth (Kasem \& Abd El-Baset, 2015; Carvalho et al., 2016; Espindula et al., 2010; Hu et al., 2017; Zhang et al., 2017a; Berry \& Spink, 2012), to increase the photosynthetic ability of plants (Zagonel \& Fernandes, 2007; Sakr, 2009), to influence the accumulation of nutrients in plants (Virych et al., 2012; Schwartau et al., 2018), to increase plant productivity and their resistance to adverse environmental factors (Matysiak, 2006; Berti et al., 2007; Shekoofa \& Emam, 2008; Hu et al., 2017; Zhang et al., 2017b; Makoveychuk et al., 2018; Mykhalska et al., 2019).

Gibberellins are a large group of diterpenoid carboxylic acids, very common in higher plants. Some of them function as endogenous growth regulators, phytohormones synthesized in young plants that grow intensively, control various aspects of plant growth and development, such as elongation of plant stems, increase in the number of internodes, induction of flowering, sex regulation, stimulation of seed germination, etc. The plant synthesizes a large number of forms of GA, but a small part of them, such as GA1 and GA4 are biologically active and perform the above functions. Concentrations of these substances are determined by the rate of their synthesis and decontamination (Ross \& O'Neill, 2001; Davière \& Achard, 2013; Hedden \& Sponsel, 2015).

Gibberelic acid (GA) in higher plants is synthesized by terpencyclases, cytochrome- $\mathrm{P}_{450}$-monooxygenases and 2-oxoglutarate-dependent dioxygenases, which are localized in the plastids, endoplasmic reticulum and cytosol, respectively. The concentration of biologically active GA in the places of their action is precisely regulated (Hedden \& Thomas, 2012). GA transport in plants is due to recently identified proteins from the NPF and SWEET families. Active GA1, for example, in pea stalks is synthesized from GA20, the enzyme that catalyzes this stage (GA-3-oxidasePsGA3ox1), encoded by the Mendel LE gene (Ross et al., 2000). Auxin promotes the biosynthesis of active gibberellin by increasing the mRNA level of the stem length gene (Ross \& O’Neill, 2001). Gibberellins interact with auxin by regulating stem elongation by regulating GA synthesis (O’Neill \& Ross, 2002).

The main catabolic pathway for GA is the 2- $\beta$-hydroxylation reaction, which is catalyzed by C19 and C20-GA2 oxidases (GA2oxs), which inactivate endogenous bioactive GA by influencing GA-dependent plant development processes (Sakamoto et al., 2004). GA promotes normal root development, preserving their morphology, due to the placement of cortical microtubules, cellulose microfibrils and other factors. Cross-links between plant hormones have also been found in signal transduction, mainly in aboveground organs. GA and indolyl-3-acetic acid (IAA) inhibit gene expression by degrading gene-repressing proteins through the ubiquitin-mediated proteasomal system. Another result of the interaction of GA and IAA in growth regulation is an increase in the level of GA1 with IAA. Because the final biochemical steps of growth regulation occur in cell walls, cross-interactions during cell wall formation and modification are also possible (Tanimoto, 2005).

Most modern retardants are inhibitors of gibberellin biosynthesis. First of all, these are onium compounds: chlormequat chloride, mepiquat chloride, chlorophonium and AMO-1618, which inhibit the conversion of geranylgeranyl pyrophosphate to ent-kauren. Subsequent conversion to ent-caurenate is catalyzed by cytochrome-P-450 dependent monooxygenases. Substances containing N-heterocycles: ancimidol, flurprimidol, tetcyclasis, paclobutrazole, uniconazole-P, and inabenfide inhibit the same enzymes of ent-kauren and ent-kaurenate formation. ACHDs effectively block GA biosynthesis pathways, reduce the content of active gibberellins GA1 and GA4, and are widely used in modern crop production (Evans, 1999; Matysiak, 2006). ACHD inhibits the final stages of GA biosynthesis, namely hydroxylation of GA20 in GA1. Trinexapac-ethyl, prohexadione- $\mathrm{Ca}$, and daminoside inhibit predominantly $3 \beta$-hydroxylation and the formation of highly active gibberellins from inactive derivatives ( $\mathrm{Ra}$ demacher, 2000; Morgun et al., 2010; Rademacher, 2010, 2016). This is confirmed by detailed studies (Evans et al., 1999), which found that the structure of the prohexadione molecule is similar to 2-oxoglutaric acid, which is a co-substrate of deoxygenases that catalyze the hydroxidation of late stages of GA biosynthesis. Therefore, the primary site of action of calcium prohexadione may be $3 \beta$-hydroxylation. As a result of the use of prohexadione there is a decrease in the level of accumulation of GA1 (highly active PGR), which causes the accumulation of its predecessor GA20 (inactive).

Inhibitors of gibberellin synthesis are divided into three classes, each of which interrupts one of the three stages of gibberellin synthesis. The first class includes compounds of quaternary ammonium (chlormequat chloride or CCC, mepiquat chloride and AMO-1618) and phosphonium (chlorochloride), which block the synthesis of entcaurenes from geranylgeranyldiphosphate. AMO-1618 and CCC specifically inhibit the activity of copalyldiphosphate synthase and, to a lesser extent, n-kauren synthase. The second class consists of nitrogen-containing heterocyclic compounds such as ancimidol (pyrimidine), tetracyclases and triazoletype compounds (paclobutrazole and uniconazole). These compounds inhibit the oxidation of ent-kauren to ent-kaurenic acid by $\mathrm{P}_{450}$ monooxygenases in stage 2 of gibberellin biosynthesis.

The third class includes ACHDs, which inhibit 2-oxoglutarate-dependent dioxygenases in stage 3 of gibberellin biosynthesis (Rademacher, 2000, 2016; Srivastava, 2003).

ACHDs are easily absorbed through the leaf surface and move acropetally, basipetal movement is limited. They can be effective both when introduced at the beginning of the plant in the tube, and in the phase of the flag leaf, when the growth of the last sub-ear internode is activated. During this period, all the elements of the ear are already laid, so the use of ACHD derivatives does not have a pronounced negative impact on plant productivity (Espindula, 2009; Morgun, 2010, 2015).

It is known that the mechanism of action of phytohormones is closely related to changes in the content of inorganic elements in plants (Marschner, 1995; Chen, 1998; Bray, 2000; Battal, 2004; Marschner, 2012). GA stimulates plant growth and development, namely seed germination, transition from vegetative to generative development, from juvenile to formed leaf, determines the course of the generative phase and grain development along with the interaction of various environmental factors light, temperature and water (Hedden, 2016). The relationship between the manifestation of biological activity of GA and the content of a number of trace elements in plants, including iron (Bray et al., 2000; Rademacher, 2000; Battal, 2004) is known. For example, changes in the content of ions in plants due to the action of the derivative ACHD trinexapac-ethyl on winter wheat (Virych et al., 2012).

Application of high doses of nitrogen fertilizers to maximize plant productivity potential, excess moisture, crop density, pests and diseases, etc., leads to elongation and loss of mechanical strength of plant stems, which prevents yields obtaining the expected quality and complicates their collection (Berry et al., 2004-2019; Shekoofa \& Emam, 2008; Zhang et al., 2017b). For spring wheat in Argentina, it was found that lodging depends on plant height, ear weight and size of the basal part of the stem (Mirabella et al., 2019). Berry \& Spink (2012) determined that little work is devoted to the mechanisms of wheat lodging. The authors hypothesized that yield losses during lodging could be predicted by a decrease in crop photosynthesis due to changes in its architecture. In this case, in fact, only retardants are a tool to achieve the target height of plants. Derivatives of $\mathrm{ACHD}$, in particular dominoside, prohexadione-Ca and trinexapac-ethyl, cause growth retardation, block 3- $\beta$-hydroxylation, inhibiting the formation of highly active GA from inactive precursors (Rademacher, 2000, 2016). Inhibition is the result of competition with a natural co-substrate, 2oxoglutarate, at the active site of hydroxylases, which are involved in later stages of gibberellin biosynthesis (GA) (Brown et al., 1997). Thus, prohexadione-Ca and trinexapac-ethyl slow down the vegetative growth of apple, tomato, sorghum, wheat and rapeseed. These compounds effectively block GC biosynthesis pathways, reducing the content of active gibberellins GC1 and GC4 (Rademacher, 2000; The Pesticide Manual, 2018). Due to the structural similarity between ACHD derivatives and 2-oxaglutaric acid, which is a co-substrate for dioxygenases, GA metabolism is blocked. Enzymatic kinetics data show a high affinity of retardants for 2oxaglutarate. Hydroxylation at position $3 \beta(\mathrm{eg}$, the formation of GA1 with GA20) and at position $2 \beta$ (e.g., the conversion of GA1 to GA8) are the main targets of ACHD. Decreased plant growth is accompanied by a decrease in biologically active forms - GA1 and its metabolite GA8 and an increase in GA20 and other precursors of GA1 (Rademacher, 2000, 2016; Srivastava, 2003) 


\section{Features of action of the acylcyclohexadione retardants}

In modern crop production, trinexapac-ethyl and prohexadione-calcium quickly replace the use of known retardants of the ethyleneproducing class, in particular, ethephon. The active substances of ACHD derivatives are free acids of trinexapac and prohexadione. Prohexadione is formed almost immediately after dissolving the calcium salt of the retardant in water. In compositions with ammonium sulfate, the activity of prohexadione-Ca in aqueous solutions increases with increasing levels of the active substance - acid in the presence of ammonium ion, as well as with the removal of calcium ions from the solution after the formation of insoluble calcium sulfate. Instead, trinexapac is formed after deesterification of ethyl. If weather conditions and the condition of plants limit the values of hydrolytic activity of plant tissues, the formation of the biologically active metabolite - trinexapac acid and, accordingly, the display of retardant activity can be delayed in time. In this case, the receipt of the retardant to the plants in the form of ether is insensitive to increased activity in the presence of ammonium ions. With the introduction of prohexadione-Ca compositions with trace elements, a decrease in the activity of the retardant may be observed due to the inhibitory effect of divalent and trivalent metals on the supply of pesticide in the form of acid.

There are differences in the use of modern retardants in the phases of development. Ethephon is used mainly at an earlier date, in the middle of the tillering phase, and at lower temperatures. If wheat and a number of other cereals - rice, oats react to the use of ethephon, then barley is insensitive to the retardant. In general, ACHD derivatives are used in later phases and their use is possible at elevated temperatures, both in wheat and barley varieties.

An underdeveloped root system can limit the ability of plants to use water and nutrients, as well as increase their risk of lodging shortly before harvest. Under the action of these derivatives of the ACHD class there is also increased branching of the root system (Morgun et al., 2010). The use of growth regulators, inhibitors of gibberellin formation, can promote better rooting and consolidation of plants in the soil, increase their root system, only by inhibiting cell elongation, without interfering with the mitotic process, stimulating tillering and avoid lodging (March et al., 2013). The use of ACHD derivatives promotes the development of the root system of wheat, which is a factor in improving the efficiency of moisture and nutrients.

Prohexadione-Ca and trinexapac-ethyl (Benetoli da Silva et al., 2011) are used to strengthen the structure of the wheat stem by reducing plant height and increasing the wall diameter (Matysiak, 2006; Simmons et al., 2017), which leads to increased plant productivity (Pricinotto et al., 2015; Trethewey et al., 2016; Koch et al., 2017a; Pinheiro et al., 2018). Timely use of retardants can help increase wheat yields by redistributing dry matter at moderate levels of lodging (Shekoofa \& Emam, 2008). The increase in grain yield is the result of morphological changes in plant architecture (Kong et al., 2013; Wang et al., 2016), which are becoming increasingly adapted to better use of environmental resources, increase in cell numbers and chlorophyll content in flag leaves (Ervin \& Koski, 2001; Pal et al., 2005; Zagonel \& Fernandes, 2007), and prolongation of photosynthetic activity.

Trinexapac-ethyl [(4-cyclopropyl- $\alpha$-hydroxymethylene) $-3,5$-dioxycyclohexanmethyl carboxylic acid ester] was discovered in 1982. Trinexapac-ethyl delays cell elongation at the end of the mevalonic acid pathway by inhibiting hydroxylation of GA20 to physiologically active GA1 and the regulatory enzyme 3- $\beta$-hydroxylase (Adams et al., 1992; Rademacher et al., 1992; Fagerness et al., 1998, 2004; Hedden \& Thomas, 2012). Trinexapac-ethyl reduces the activity of gibberellins, in particular GA1, by reducing the activity of the enzyme GA20-3B-hydroxylase, which prevents cell elongation, shortens the internodes, increases stem diameter and reduces lodging (Chastain et al., 2014). Inhibition of the activity of this enzyme is probably due to competition between the growth regulator and 2-oxoglutarate for the co-substrate $\mathrm{Fe}^{+2}$ /ascorbate-dependent dioxygenase (Adams et al., 1992).

The active substance trinexapac-ethyl, which is part of commercial retardant preparations, is used in agriculture to prevent lodging of cereals in a wide range of developmental stages, from the beginning of tillering to the formation of the flag leaf. Trinexapac-ethyl ester is easily absorbed by the plant through the leaf surface, where it is hydrolyzed to the active form an acid derivative that moves to the meristems of plants, including the root. With the use of trinexapac-ethyl, root growth inhibition correlates with the effect of slow shoot growth. Due to the esterase activity of plant tissues, which requires time and the magnitude of activity of which depends on temperature and light, the formation of active trinexapac acid occurs. It interacts with GA12-aldehyde and blocks the biosynthesis of gibberellic acid. It is known that treatment of plants with trinexapac-ethyl can maintain or increase yields, both by reducing or avoiding lodging of crops (Matysiak, 2006; Benetoli da Silva et al., 2011) and the development of the root system, providing better rooting, which gives the ability to absorb nutrients and water more efficiently (Beasley et al., 2005), which makes plants less sensitive to stress caused by high temperatures, drought (Heckman et al., 2001; Heckman et al., 2002; McCann \& Huang, 2007; Xu \& Huang, 2011; Elansarya \& Salem, 2015) or salinization (Sattar et al., 2019). The effect of trinexapac-ethyl on the development of the root system is important under the conditions and application of the retardant in the autumn. At the same time, the best levels of overwintering of highly sensitive varieties, in particular Mediterranean varieties, are observed.

Under salt stress, the use of trinexapac-ethyl in wheat slightly improves plant growth and provides dark green leaf colour by increasing chlorophyll content and mesophilic cell density (Sattar et al., 2019), increases $\mathrm{CO}_{2}$ fixation and the formation of new non-structural carbohydrates (Ervin \& Zhang, 2007). Slow degradation of chlorophyll content also increases the efficiency of photosynthesis of plants, which increases their resistance to stress (Arghavani et al., 2012). Wheat seedlings under salt stress and trinexapac-ethyl treatment had increased antioxidant activity of enzymes (superoxide dismutase, catalase, peroxidase, ascorbate peroxidase) (Sattar et al., 2019), probably due to the lower content of malonic dialdehyde (Chen et al., 2009). Trinexapac-ethyl promotes the formation of osmotic adaptation, a phenomenon associated with the accumulation of soluble substances and inorganic ions, which lead to increased survival of plants under salt stress (Elansarya \& Salem, 2015; Koch et al., 2017b).

The use of ACHD improves the condition of the stem, prevents lodging and increases yields (Hu et al., 2017). The use of trinexapac-ethyl helps to reduce plant height, increase the content of chlorophyll in the leaves, diameter and thickness of the stem (Zagonel \& Fernandes, 2007), increases crop yields (Shekoofa \& Emam, 2008). High concentrations of trinexapac-ethyl can reduce grain yield (Espindula et al., 2009). Such anatomical features of the stem structure as strength, wall thickness of the basal internode, diameter, its filling with forming tissues, increase in lignin content, as well as plant height are the main features that are important for strengthening plants and their resistance to lodging (Islam et al., 2007; Sameri et al., 2009; Wiersma et al., 2011). Trinexapac-ethyl increases the proportion of sclerenchyma and parenchyma, wall thickness and density, as well as stem diameter, and reduces its length, which contributes to the resistance of plants to lodging (Zhang et al., 2017a). It is believed (Okuno et al., 2014) that gibberellin inhibitors reduce plant height and thus shift the center of gravity, which helps to avoid lodging of plants. Trinexapac-ethyl has a longer effect on inhibiting gibberellin biosynthesis, leading to a reduction in plant internode length (Zagonel et al., 2002).

Trinexapac-ethyl, one of the most widely used PGRs on lawn grasses in the world, is used to reduce the frequency of mowing lawn grasses, as it reduces their height and growth rate, improving the quality of the lawn (Heckman et al., 2001a, 2001b, 2002; Beasley et al., 2005; Pornaro et al., 2017). Trinexapac-ethyl inhibits cell elongation by inhibiting processes at the end of the mevalonic acid synthesis pathway by stopping the conversion of GA20 to GA1. Treatment of lawn grasses with trinexapac-ethyl produces a more intense green colour of the leaves, due to the increase in their concentration of chlorophyll and the density of mesophilic cells (Heckman et al., 2001a; Heckman et al., 2005; Baldwin et al., 2006; McCullough et al., 2006; Xiao-ying et al., 2009), and more compact leaf blades that reduce evaporation (Ervin \& Koski, 2001) and increased leaf weight (Heckman et al., 2001), as well as increased stem density in the lawn, improved tillering (Fagerness \& Yelverton, 2001; Beasley et al., 2005), which helps reduce moisture evaporation from the soil. Trinexapac-ethyl is easily absorbed through the leaf surface of plants, while the roots absorb only a small amount (Fagerness \& Penner, 1998). Thus, inhibition of root growth when using trinexapac-ethyl correlates with the effect of slow stem growth. However, in our experiments to determine the effectiveness of trinexapac-ethyl on Smuglyanka winter wheat sprouts, 
which were obtained in the laboratory on $0.9 \%$ agar, no differences between the action of the retardant through the root system or through the leaves were found. Therefore, the differences observed by the authors (Fagerness \& Penner, 1998) may be related to the interaction of trinexapac-ethyl with soil degradation, including with soil microorganisms.

The use of nitrogen in the use of trinexapac-ethyl does not increase the leaching of nitrates in lawn grasses, but increases the restoration of their fertility (Fagerness et al., 2004).

The growth regulator shortens the internodes and stem length of plants, improves seed quality, and promotes faster and better harvesting (Borm \& van den Berg, 2008; Rolston et al., 2010; Chastain et al., 2014). The use of trinexapac-ethyl increases the yield of seeds of annual and perennial grasses (Zapiola et al., 2006; Chynoweth et al., 2014; Chastain et al., 2015; Trethewey et al., 2016).

The use of trinexapac-ethyl can have a positive effect on plant resistance to various stresses, including heat and drought (Bian et al., 2014), due to its effect on increasing the photosynthetic capacity associated with increased chlorophyll content and photochemical efficiency and hydration support cells. At the same time, the improvement of the sowing architecture is considered as a key factor of lodging resistance (Feng et al., 2019; Khobra et al., 2019). Slow degradation of chlorophyll content under salinity conditions increases the efficiency of photosynthesis of plants, which increases their resistance to stress (Arghavani et al., 2012). Trinesapacethyl, which is used in spraying the leaves, promotes the accumulation of fresh and dry biomass, pigments (chlorophyll and carotenoids) in the lawn grass (Sakr, 2009), increases the content of proline and the activity of enzymes (superoxide dismutase, catalase, peroxoroxidase) in wheat shoots under salt stress (Sattar et al., 2019) and in drought, reduces the amount of malonic aldehyde (Sheikh Mohammadi et al., 2016), reducing oxidative damage to cell membranes. It also promotes the formation of osmotic adaptation, a phenomenon associated with the accumulation of soluble substances and inorganic ions, which lead to increased plant survival under salt stress (Elansarya \& Salem, 2015; Koch et al., 2017b).

The use of trinexapac-ethyl on some types of lawn grasses at low salt loads contributes to an increase in root mass, which may be one of the adaptive mechanisms, with an increased absorption surface of the root water absorption increases. However, treatment of lawn grasses with trinexapac-ethyl under high salt load can lead to a decrease in the content of $\mathrm{P}, \mathrm{K}, \mathrm{Mg}$ and $\mathrm{Ca}$ in plant tissues (Baldwin et al., 2006).

The use of trinexapac-ethyl alone and in combination with nitrogen on lawn grasses in shady conditions promotes better grass growth and increased levels of chlorophyll b in leaf tissues (Qian \& Engelke, 1999; Steinke \& Stier, 2003; Bunnell et al., 2005; Nangle et al., 2012). Trinexapac-ethyl had a positive effect on lawn grasses grown under conditions of low photosynthetic photon flux (PPF) (Qian \& Engelke, 1999; Goss et al., 2002; Steinke \& Stier, 2003; Bunnell et al., 2005).

The use of trinexapac-ethyl may be negative, as it shows structural similarity to 2-oxoglutaric acid (Rademacher, 2014). It is believed that the use of trinexapac-ethyl affects the content of flavonoids resulting from the inhibition of 2-oxoglutaric acid, a co-substrate for oxygenases that catalyze the metabolism of gibberellin at a late stage and the formation of lightabsorbing flavonoids (Rademacher, 2000). Decreased flavonoid levels with trinexapac-ethyl may be associated with damage at higher light intensities than in shady conditions. This can be explained by the slight phytotoxic effect that may occur after the use of trinexapac-ethyl (Wiecko \& Couillard, 1997). The production of flavonoids is induced by high red light, ultraviolet light can inhibit their formation (Buchholz et al., 1995). Plants with low flavonoid content have the ability to absorb ultraviolet-B, which leads to photodamage to the leaves (Lau et al., 2006).

In long-term experiments of CIMMYT and other leading scientific centers of the world, in experiments on phenotyping of varieties (Xiao et al., 2015; Piñera-Chavez et al., 2016; Shah et al., 2019) and the root system of plants (Dreccer et al., 2020) traits are identified that can distinguish genotypes with low levels of lodging and high productivity.

Prohexadione-Ca (3,5-dioxo-4-propionylcyclohexanecarboxylate calcium) was developed jointly by BASF (Limburgerhof, Germany) and Kumiai Chemical Industry (Tokyo) (Kim et al., 2007; The Pesticide Manual, 2018). Its molecular structure is similar to trinexapac-ethyl (Rademacher, 2000). It, like trinexapac-ethyl, inhibits the late stages of GA

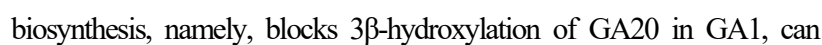
cause resistance to bacterial infections of apple and pear leaves caused by Erwinia amylovora and Venturia inaequalis (McGrath et al., 2009; Paulson et al., 2005), by inhibiting flavanone-3 $\beta$-hydroxylase and flavonol synthase, which causes changes in flavonoid metabolism. Due to the similarity of the structure of prohexadione and trinexapac to 2-oxyglutarate, ACHDs increase resistance by inhibiting iron (II), 2-oxyglutaratedependent dioxygenases (eg, flavanone-3 $\beta$-hydroxylase, and flavonol synthase), which play an important role in flavonoid biosysnsesis (Puhl et al., 2008) and acted as competitive inhibitors of 2-oxyglutaratedependent enzymes in the pathway of gibberellin biosynthesis. Prohexadione-Ca, like trinexapac-ethyl, can act as an inhibitor of ethylene synthesis (Rademacher, 2000, 2014). The substance is freely absorbed through the leaf surface and moves acropetally, basipetal movement is limited. Drugs whose active ingredient is prohexadione-Ca are characterized by good retardant action and a wide range of phases and application temperatures. The use of the drug in the direction of reducing the height of the plant and strengthening the straw is effective in the phases from the beginning of the plants in the tube and to the flag leaf, when there is growth of the sub-ear internode. Reducing the height of plants, including by inhibiting the growth of the last internode, reduces the wind exposure of crops and increases resistance to lodging. Prohexadione-Ca can also be used from the middle of the tillering phase to increase the tillering of plants.

Prohexadione-Ca, like trinexapac-ethyl, is widely used to control the vegetative growth of plants, which prevents lodging and helps maintain plant productivity (Na et al., 2011; Pinheiro et al., 2018), accelerates harvesting. The use of growth inhibitors can increase grain yield not only by reducing lodging, but also by increasing the absorption of solar radiation, changing stem diameter, leaf size and stimulating root growth (Pricinotto et al., 2015), as well as erectility of plants and leaves (Virych et al., 2012). Treatment of trinexapac-ethyl wheat plants does not have a negative effect on the chemical composition, germination and energy of seed germination and the emergence of seedlings (Koch et al., 2017a, 2017b). It was found that the use of trinexapac-ethyl reduces the negative impact on wheat seedlings of salt stress by improving growth, water metabolism, chlorophyll content (Sattar et al., 2019).

It was found (Vavilala et al., 2014) that daminozide selectively inhibits KDM2/7-dimethylase (Rose et al., 2012). For example, daminozide, as a prohexadione-like analogue of 2-oxoglutarate and PGR, has been banned due to its effects on human health. The Environmental Protection Agency classifies prohexadione as a low-risk pesticide due to its low toxicity and limited resistance to the environment due to photo- and microbial degradation (Paulson et al., 2005; Choi et al., 2011). Although it meets the criteria of reduced environmental risk for pesticides, for prohexadione, in our opinion, it is necessary to establish clear "maximum residues" to ensure its safe use in food production.

Prohexadione-like structures are more active than methyl or ethyl ethers, probably due to a higher degree of similarity to 2-oxaglutaric acid. Long acyl side chains lead to increased inhibitory activity compared to shorter ones. Note that too long chains are phytotoxic to intact plants. Thus, ethyl or cyclopropyl substituents are likely to be optimal. In addition, esters are better absorbed by the leaves after spraying than ionized forms, and are easier to produce.

\section{The role of calcium in the activity of trinexapac-ethyl}

Calcium ions are considered as a universal regulator of many reactions in cells involved in the conduction of various signals that carry out the primary action - hormones, pathogens, light, gravitational and stress reactions, and so on. $\mathrm{Ca}^{2+}$ ions are important as a secondary mediator in each of the signal transduction systems known to plants. Calcium is an effective regulator of metabolic processes in all cells where there are systems that respond to small changes in its concentration (Schwartau et al., 2014). Using inhibitory analysis, the participation of $\mathrm{Ca}^{2+}$ in signal transduction into the cell and the regulation of growth processes controlled by gibberellic acid are investigated. The main intracellular mediator of signal transmission from $\mathrm{GA}$ is the $\mathrm{Ca} / \mathrm{Ca}$-calmodulin system. Changes in the concentration of cytoplasmic $\mathrm{Ca}^{2+}$ allow us to determine the features of 
the mechanisms of action of trinexapac-ethyl on wheat cells and the plant body as a whole (Schwartau et al., 2014).

Free cytosolic calcium in the plant cell at rest is maintained at a low level (about 100-200 nm). The increase in the concentration of cytoplasmic $\mathrm{Ca}^{2+}$ occurs in response to the stimulus, and then quickly returns to baseline. On the other hand, the level of $\mathrm{Ca}^{2+}$ in the cell wall (apoplast) and some organelles (vacuoles and endoplasmic reticulum) is 3-4 orders of magnitude higher than cytosolic $\mathrm{Ca}^{2+}$. With increasing concentrations of intracellular calcium, activation of various protein kinases and phospholipases takes place. That is, $\mathrm{Ca}^{2+}$ regulates not only the activation of amylase during seed germination, but also photosynthetic and energy processes in plant cells.

When comparing the fluorescence of the apical zone of intact winter wheat seedlings treated with trinexapac-ethyl with control, there was a decrease (by 36-52\%) in the amount of free cytosolic calcium, indicating a possible inactivation of calcium transport systems in the cell and a decrease in synthesized gibberellin acid.

Gibberellin acid transmits its signals to the cell through receptors that are indirectly linked to the calcium/calmodulin system. In the control a fairly significant level of cytosolic calcium and its uniform distribution throughout the cell was observed. In the experimental variants, the main amount of intracellular calcium was localized in vacuoles, which are calcium depots of the cell, resulting in a sharp drop in the level of free cytoplasmic calcium. In this case, energy-dependent calcium channels, which pump calcium into the depot or release it into the intercellular space, probably worked actively. Because trinexapac-ethyl blocks the synthesis of gibberellic acid, the $\mathrm{Ca} / \mathrm{Ca}$-calmodulin system breaks down and releases $4 \mathrm{Ca}^{2+}$ ions per molecule of calmodulin, which can lead to an increase in cytoplasmic $\mathrm{Ca}^{2+}$.

It is suggested (Gilroy et al., 1993) that GA alters the flow of $\mathrm{Ca}^{2+}$ in the plasmalemma. The mechanism is unknown, although it is hypothesized that the GA receptor directly or indirectly regulates the membrane calcium channel, possibly through a heterotrimeric $\mathrm{G}$ protein. $\mathrm{Ca}^{2+}$ is also released from intracellular depots. There is a close association between auxins and gibberellins (Ross et al., 2000). As the synthesis of GA is disturbed, the synthesis of auxins may increase. The auxin signaling system is associated with $\mathrm{Ca}^{2+}$, so an increase in cytoplasmic $\mathrm{Ca}^{2+}$ is possible.

Thus, under the action of trinexapac-ethyl on the roots of winter wheat seedlings, an increase in calcium in vacuoles is observed, possibly due to the activation of $\mathrm{Ca}^{2+} / \mathrm{H}^{+}$-pumps and $\mathrm{Ca}^{2+}$-ATPases. Thus, reducing the amount of free cytoplasmic calcium in the intact roots of winter wheat by processing their trinexapac-ethyl can help in understanding the mechanism of its action on plants.

The results of the studies revealed the effect of trinexapac-ethyl on root meristematic cells and a decrease in the activity of the concentration of cytoplasmic $\mathrm{Ca}^{2+}$ in cells. This can reduce the level of cell metabolism and its sensitivity to external influences, which reduces the mitotic index of tissue and increases resistance to adverse conditions that we see in the external, visually identified, morphological characteristics of plants.

\section{Influence of ACHD derivatives on productivity of cereals}

The key to the feasibility of using retardants is to increase crop productivity to control lodging. However, even on semidwarf varieties of winter wheat, which practically do not lodge, for example - Smuglyanka, the use of retardants of the ACHD class leads to increased productivity. At the same time, the efficiency of trinexapac-ethyl when added to the $\mathrm{BBCH} 30$ phase is often higher in comparison with the use in the $\mathrm{BBCH} 37$ phase. From the experience of field tests, it is expedient to apply the maximum dose of trinexapac-ethyl $-150 \mathrm{~g} /$ ha, both once in $\mathrm{BBCH} 30$ and by dividing the dose of retardant into two applications. When applying the dose of trinexapac-ethyl, from $50 \%$ and more is administered in the first spraying.

For the first time in our experiments, we found the effectiveness of trinexapac-ethyl in the autumn on Mediterranean wheat variety Zimoyar$\mathrm{ka}$ in the 2011-2012 season. In further experiments, the effectiveness of its application on semidwarf varieties of winter wheat was established. According to numerous studies in all soil and climatic zones of Ukraine, the use of trinexapac-ethyl in the autumn for half of its dose (50-75 g/ha) enhances the development of the root system to $+12-25 \%$ of dry matter, promotes the development of the secondary root system, increases the tillering ratio by $0.16-0.88$, promotes the growth of sugars in the tillering nodes up to $6 \%$ on dry matter, better prevents lodging in the second half of the growing season. All this improves the winter hardiness of plants, resistance to lodging and adverse weather conditions in the spring, in particular due to the earlier and more powerful development of the nodular root system. Numerous examples from farms in recent years, especially with intensive cultivation technology, confirm the feasibility of using trinexapac-ethyl in the autumn on high-yield varieties. This approach is becoming more popular every year and is used on tens of thousands of hectares of intensive varieties of winter wheat and winter barley in Ukraine (Dubrovin, 2020, personal communication).

It should also be noted that in intensive technologies for growing barley hybrids on both dryland and under irrigation, the use of trinexapacethyl promotes enhanced root system development, post-overwintering condition and the effectiveness of controlling crop lodging in the second half of the growing season. Therefore, with the introduction of winter barley hybrids into production, a component of the technology is the introduction of trenexapac-ethyl in doses of 50-75 g/ha in autumn.

The effect of ACHD derivatives on promoting the development of the root system may increase the accumulation of biologically important metals, especially potassium (Vyrich et al., 2012) with a corresponding increase in the efficiency of plant nutrients in crops. Increasing the accumulation of potassium, as the main inorganic osmotic in plant cells under the action of trinexapac-ethyl, is important to increase frost and winter hardiness of crops.

An important feature of the action of ACHD derivatives is the effect on the level of tillering of cereals in crops. With the predominance as precursors of late crops: sunflower, soybean and corn, it is important to use ACHD derivatives to enhance productive tillering.

In the regions of Ukraine, primarily in the grain belt, prohexadione$\mathrm{Ca}$ is widely used in highly effective composite preparations of retardants in winter wheat crops in late sowing, where in the autumn there was limited or no productive tillering, as well as in crops which were thinned out during the winter in order to increase the number of lateral shoots. In this case, prohexadione-Ca with mepiquat chloride is used during the period of culture development from three leaves to the middle of tillering $(\mathrm{BBCH}$ 13-25). With high levels of nitrogen nutrition, from $\mathrm{N}_{90-100}$ and above, to prevent lodging of crops, prohexadione- $\mathrm{Ca}^{+}$mepiquat chloride should be applied once in the phase of the beginning of plants in the tube (BBCH $30-32$ ) or at the appearance of a flag leaf (BBCH 37-39). When applying $\mathrm{N}_{110-150}$, and more in some fields, as well as on crops of tall varieties of winter wheat, it is advisable to use a double application of retardant: the first in the phase of the beginning in the tube $\mathrm{BBCH} 30-32$, the second during the appearance of the flag leaf $\mathrm{BBCH} 37-39$.

The influence of ACHD derivatives on the development of the root system, the number of productive shoots, the levels of chlorophyll accumulation can also increase the efficiency of the use of moisture and nutrients by plants in crops. However, an important feature of the action of ACHD derivatives is the formation of a thickened cell wall of the plant, which in turn leads to counteracting the lodging of the plant in the crop. In this case, for this thickening of the cell wall, the plant spends additional carbon pools with a corresponding restriction of its redistribution in the generative organ.

It should be noted that the vast majority of modern wheat varieties have a hollow core of the stem (Pask et al., 2012; Reynolds et al., 2012; Bainsla et al., 2020). In this case, the parenchymal cells of the stem core in a number of varieties are important for the accumulation of high levels of assimilates with subsequent redistribution of the pool of assimilates from stem to ear. The solidity of the stem is a hereditary trait, and the levels of solidity of the stem can change at high temperatures or water deficiency. Also, the levels of wheat solidity are associated with the development of culture resistance to Cephus cinctus Norton (Hymenoptera: Cephidae) (Hayat et al., 1995; Bainsla et al., 2020). Thus, the limited influence of ACHD derivatives on the productivity of cereal crops in numerous experiments, primarily in the absence of moisture, may be varietal-specific and may be related to the peculiarities of the effect of retardants on the solidity of stem internodes of individual varieties. Of course, the study of the effect 
of ACHD derivatives on the level of carbon accumulation in the stems with subsequent redistribution to the ear on the main varieties and hybrids used in production requires additional research.

\section{Conclusions}

Control of lodging of crops of cereals and other crops is an important component of achieving high productivity and profitability of agricultural production. ACHD retardants are widely used in modern crop production. Derivatives of this class are promising in the treatment of a number of diseases, including cancer, and the detoxification of a number of substances in bacteria. Therefore, in addition to retardant activity and numerous morphological and physiological effects, their study in the direction of regulating the metabolism of xenobiotics is promising, especially when used in compositions with other pesticides and agrochemicals. It should be noted that this class of retardants continues to be studied by numerous laboratories in the world and remains among the most promising for the creation of new highly effective agrochemicals. Regarding the established differences in the effectiveness of ACHD retardants in different varieties and hybrids, this area requires further extensive research on production. Given the high varietal variability of the effectiveness of the use of ACHD derivatives in cereals, it is advisable to conduct registration and post-registration studies on varieties that occupy the largest sown areas in the country. Also, the issues that need to be studied in more detail include finding out the impact of ACHD derivatives on the productivity of cereals. When controlling lodging, the influence of ACHD on the productivity of crops of cereals, primarily barley and wheat, is obvious. However, the effect of ACHD derivatives on stem contraction, especially on the reduction of the upper, subcortical, internodes, can reduce carbon pools, which are redistributed to the generative organs with a corresponding decrease in productivity. This effect can be especially pronounced in the absence of moisture in the second half of the growing season.

The authors express deep gratitude to the specialists of the Experimental Agricultural Station of the Institute of Plant Physiology and Genetics of the National Academy of Sciences of Ukraine (Kyiv region), Syngenta and BASF for many years of cooperation and assistance in conducting experiments.

\section{References}

Adams, R., Kerber, E., Pfister, K., \& Weiler, E. W. (1992). Studies on the action of the new growth retardant CGA163'935 (Primo). In: Karssen, C. M., van Loon, L. C., \& Vreugdenhil, D. (Eds.). Progress in plant growth regulations. Kluwer Academics, Amsterdam. Pp. 818-827.

Altintas, S. (2011). Effects of chlormequat chloride and different rates of prohexadione-calcium on seedling growth, flowering, fruit development and yield of tomato. African Journal of Biotechnology, 10(75), 17160-17169.

Arghavani, M., Kafi, M., Babalar, M., Naderi, R., Hoque, M. A., \& Murata, Y. (2012). Improvement of salt tolerance in Kentucky bluegrass by trinexapacethyl. Journal of the American Society for Horticultural Science, 47(8), 11631170 .

Bainsla, N. K., Yadav, R., Singh, G. P., \& Sharma, R. K. (2020). Additive genetic behavior of stem solidness in wheat (Triticum aestivum L.). Scientific Reports, $10(1), 7336$

Baldwin, C. M., Liu, H., McCarty, L. B., Bauerle, W. L., \& Toler, J. E. (2006). Effects of trinexapac-ethyl on the salinity tolerance of two bermudagrass cultivars. Journal of the American Society for Horticultural Science, 41(3), 808-814.

Battal, P. (2004). Effects of some mineral nutrients on gibberellic acid levels in maize plants (Zea mais L). Economic Botany, 58(2), 195-203.

Beasley, J. S., Branham, B. E., \& Ortiz-Ribbing, L. M. (2005). Trinexapac-ethyl affects Kentucky bluegrass root architecture. Journal of the American Society for Horticultural Science, 40(5), 1539-1542.

Benetoli da Silva, T. R., Schmidt, R., Tavares da Silva, C. A., Nolla, A., Favero, F., \& Poletine, J. P. (2011). Effect of trinexapac-ethyl and nitrogen fertilization on wheat growth and yield. Journal of Food, Agriculture and Environment, 9, 596-598.

Berry, P. M., \& Spink, J. (2012). Predicting yield losses caused by lodging in wheat. Field Crops Research, 137, 19-26.

Berry, P. M., Sterling, M., \& Mooney, S. J. (2006). Development of a model of lodging for barley. Journal of Agronomy and Crop Science, 192(2), 151-158.

Berry, P. M., Sterling, M., Spink, J. H., Baker, C. J., Sylvester-Bradley, R., Mooney, S. J., \& Ennos, A. R. (2004). Understanding and reducing lodging in cereals. Advances in Agronomy, 84, 217-271.
Berry, P., Blackburn, A., Sterling, M., Miao, Y., Hatley, D., Gullick, D., Joseph, G., Whyatt, D., Soper, D., Murray, J., \& Baker, C. (2019). A multi-disciplinary approach for the precision management of lodging risk. In: Stafford, J. V. (Ed.), 12th European Conference on Precision Agriculture, ECPA 2019 (963-975). Wageningen Academic Publishers.

Berti, M., Zagonel, J., \& Fernandes, E. C. (2007). Produtividade de cultivares de trigo em função do trinexapac-ethyl e doses de nitrogênio [Yield of wheat cultivars in function of trinexapac-ethyl and nitrogen rates]. Scientia Agraria, 8(2), 127-134 (in Portuguese)

Bian, X., Merewitz, E., \& Huang, B. (2009). Effects of trinexapac-ethyl on drought responses in creeping bentgrass associated with water use and osmotic adjustment. Journal of the American Society for Horticultural Science, 134(5), 505-510.

Borm, G. E. L., \& van den Berg, W. (2008). Effects of the application rate and time of the growth regulator trinexapac-ethyl in seed crops of Lolium perenne L. in relation to spring nitrogen rate. Field Crops Research, 105(3), 182-192.

Bray, E. A., Bailey-Serres, J., \& Weretilnyk, E. (2000). Responses to abiotic stresses. Biochemistry and molecular biology of plants. In: Buchanan, B. B., Gruissem, W., \& Jones, R. L. (Eds.). American Society of Plant Physiologists, Rockville. , Pp. 1158-1203.

Brown, R. G. S., Kawaide, H., Yang, Y. Y., Rademacher, W., \& Kamiya, Y. (1997). Daminozide and prohexadione have similar modes of action as inhibitors of the late stages of gibberellin metabolism. Physiologia Plantarum, 101(2), 309-313.

Buchholz, G., Ehmann, B., \& Wellmann, E. (1995). Ultraviolet light inhibition of phytochromeinduced flavonoid biosynthesis and DNA photolyase formation in mustard cotyledons (Sinapis alba L.). Plant Physiology, 108, 227-234.

Bunnell, B. T., McCarty, L. B., \& Bridges, W. C. Jr. (2005). 'TifEagle' bermudagrass response to growth factors and mowing height when grown at various hours of sunlight. Crop Science, 45(2), 575-581.

Carvalho, M. E. A., Castro, P. R. de C. e, Ferraz Junior, M. V. de C., \& Mendes, A. C. C. M. (2016). Are plant growth retardants a strategy to decrease lodging and increase yield of sunflower? Comunicata Scientiae, 7(1), 154-159.

Chastain, T. G., Young III, W. C., Garbacik, C. J., \& Silberstein, T. B. (2015). Trinexapac-ethyl rate and application timing effects on seed yield and yield components in tall fescue. Field Crops Research, 173, 8-13.

Chastain, T. G., Young III, W. C., Silberstein, T. B., \& Garbacik, C. J. (2014). Performance of trinexapac-ethyl on Lolium perenne seed crops in diverse lodging environments. Field Crops Research, 157, 65-70.

Chen, C., Lu, S., Chen, Y., Wang, Z., Niu, Y., \& Guo, Z. (2009). A gamma-ray induced dwarf mutant from seeded bermudagrass and its physiological responses to drought stress. Journal of the American Society for Horticultural Science, 134(1), 22-30.

Chen, J.-G., Cheng, S.-H., Cao, W., \& Zhou, X. (1998). Involvement of endogenous plant hormones in the effect of mixed nitrogen source on growth and tillering of wheat. Journal of Plant Nutrition, 21(1), 87-97.

Choi, J. H., Yoon, H. J., Do, J. A., Park, Y. C., Kim, J. H., \& Choi, D. (2011). An analytical method for prohexadione in Chinese cabbage and apple. Biomedical Chromatography, 25(4), 493- 497.

Chynoweth, R. J., Trethewey, J. A. K., Rolston, M. P., \& McCloy, B. L. (2014). Reduced stem length increases perennial ryegrass seed yield. Agronomy New Zealand, 44, 61-70.

Davière, J. M., \& Achard, P. (2013). Gibberellin signaling in plants. Development, $140,1147-1151$.

Dreccer, M. F., Condon, A. G., Macdonald, B., Rebetzke, G. J., Awasi, M.-A., Borgognone, M. G., Peake, A., Piñera-Chavez, F. J., Hundt, A., Jackway, P., \& McIntyre, C. L. (2020). Genotypic variation for lodging tolerance in spring wheat: Wider and deeper root plates, a feature of low lodging, high yielding germplasm. Field Crops Research, 258(1), 107942.

Elansarya, H. O., \& Salem, M. Z. M. (2015). Morphological and physiological responses and drought resistance enhancement of ornamental shrubs by trinexapac-ethyl application. Scientia Horticulturae, 189, 1-11.

Ervin, E. H., \& Koski, A. J. (2001). Trinexapac-ethyl increases kentucky bluegrass leaf cell density and chlorophyll concentration. Journal of the American Society for Horticultural Science, 36(4), 787-789.

Ervin, E. H., \& Zhang, W. (2007). Influence of sequential trinexapac-ethyl applications on cytokinin content in creepingbentgrass, kentucky bluegrass, and hybrid bermudagrass. Crop Science, 47(5), 2145-2151.

Espindula, M. C., Rocha, V. S., Grossi, J. A. S., Souza, M. A., Souza, L. T., \& Favarato, L. F. (2009). Use of growth retardants in wheat. Planta Daninha, 27, 379-387.

Espindula, M. C., Rocha, V. S., Souza, L. T., Souza, M. A., \& Grossi, M. A. S. (2010). Effect of growth regulators on wheat stem elongation. Acta Scientiarum Agronomy, 32(1), 109-116.

Evans, J. R., Evans, R. R., Regusci, C. L., \& Rademacher, W. (1999). Mode of action, metabolism, and uptake of BAS $125 \mathrm{~W}$, prohexadione-calcium. Journal of the American Society for Horticultural Science, 34(7), 1200-1201.

Fagemess, M. J., \& Penner, D. (1998). ${ }^{14} \mathrm{C}$-trinexapac-ethyl absorption and translocation in Kentucky bluegrass. Crop Science, 38(4), 1023-1027. 
Fagemess, M. J., \& Yelverton, F. H. (2001). Plant growth regulator and mowing height effects on seasonal root growth of Penncross creeping bentgrass. Crop Science, 41(6), 1901-1905.

Fagemess, M. J., Bowman, D. C., Yelverton, F. H., \& Rufty, T. W. (2004). Nitrogen use in Tifway bermudagrass, as affected by trinexapac-ethyl. Crop Science, 44(2), 595-599.

Feng, S., Kong, D., Ding, W., Ru, Z., Li, G., \& Niu, L. (2019). A novel wheat lodging resistance evaluation method and device based on the thrust force of the stalks. PLoS One, 14(11), e0224732.

Gilroy, S., Bethke, P. C., \& Jones, R. L. (1993). Calcium homeostasis in plants. Journal of Cell Science, 106, 453-461.

Goss, R. M., Baird, J. H., Kelm, S. L., \& Calhoun, R. N. (2002). Trinexapac-ethyl and nitrogen effects on creeping bentgrass grown under reduced light conditions. Crop Science, 42(2), 472-479.

Hayat, M. A., Martin, J. M., Lanning, S. P., McGuire, C. F., \& Talbert, L. E. (1995). Variation for stem solidness and its association with agronomic traits in spring wheat. Canadian Journal of Plant Science, 75(4), 775-780.

Heckman, N. L., Gaussoin, R. E., Horst, G. L., \& Elowsky, C. G. (2005). Growth regulator effects on cellular characteristics of two turfgrass species. International Turfgrass Society Research Journal, 10, 857-861.

Heckman, N. L., Horst, G. L., \& Gaussoin, R. E. (2001). Trinexapac-ethy influences specific leaf weight and chlorophyll content of Poa pratensis. International Turfgrass Society Research Journal, 9, 287-290.

Heckman, N. L., Horst, G. L., Gaussoin, R. E., \& Tavener, B. T. (2002). Trinexapacethyl influence on cell membrane thermostability of Kentucky bluegrass leaf tissue. Scientia Horticulturae, 92(2), 183-186.

Heckman, N. L., Horst, G., Gaussoin, R. E., \& Young, L. J. (2001). Heat tolerance of Kentucky bluegrass as affected by trinexapac-ethyl. Journal of the American Society for Horticultural Science, 36(2), 365-367.

Hedden, P. (2003). The genes of the green revolution. Trends in Genetics, 19(1), 5-9.

Hedden, P., \& Sponsel, V. (2015). A century of gibberellin research. Journal of Plant Growth Regulation, 34, 740-760.

Hedden, P., \& Stephen, G. T. (Eds.). (2016). Annual plant reviews, 49. The Gibberellins. John Wiley \& Sons, Ltd.

Hedden, P., \& Thomas, S. G. (2012). Gibberellin biosynthesis and its regulation. Biochemical Journal, 444(1), 11-25.

Islam, M. S., Peng, S., Visperas, R. M., Ereful, N., Bhuiya, M. S. U., \& Julfiquar, A. W. (2007). Lodging-related morphological traits of hybrid rice in a tropical irrigated ecosystem. Field Crops Research, 101, 240-248.

Kasem, M. M., \& Abd El-Baset, M. M. (2015). Studing the influence of some growth retardants as a chemical mower on ryegrass (Lolium perenne L.). Journal of Plant Sciences, 3(5), 255-258.

Khobra, R., Sareen, S., Meena, B. K., Kumar, A., Tiwari, V., \& Singh, G. P. (2019). Exploring the traits for lodging tolerance in wheat genotypes: A review. Physiology and Molecular Biology of Plants, 25(1), 589-600.

Kim, H. Y., Lee, I. J., Hamayun, M., Kim, J. T., Won, J. G., Hwang, I. C., \& Kim, K. U. (2007). Effect of prohexadione calcium on growth components and endogenous gibberellins contents of rice (Oryza sativa L.). Journal of Agronomy and Crop Science, 193(6), 445-451.

Koch, F., Aisenberg, G., Monteiro, M., Pedó, T., Zimmer, P., Villela, F., \& Aumonde, T. (2017a). Growth of wheat plants submitted to the application of the growth regulator trinexapac-ethyl and vigor of the produced seeds. Agrociencia Uruguay, 21(1), 24-32.

Koch, F., Zimmer, G., Monteiro, M. A., Martins, A. C., Delias, D. S., Troyjack, C., Szareski, V. J., Borges, E. G., Pedó, T., Amarante, L., Villela, F. A., \& Aumonde, T. Z. (2017b). Chemical composition and physiological quality of wheat seeds with the application of trinexapac-ethyl, a plant growth regulator. Australian Joumal of Crop Science, 11(12), 1527-1533.

Kong, E., Liu, D., Guo, X., Yang, W., Sun, J., Li, X., Zhan, K., Cui, D., Lin, J., \& Zhang, A. (2013). Anatomical and chemical characteristics associated with lodging resistance in wheat. The Crop Journal, 1(1), 43-49.

Kuryata, V. G., \& Shataliuk, H. S. (2020). Diya giberelinu i retardantiv na pererozpodil vuglevodiv ta elementiv zhyvlennya $\mathrm{v}$ lystkah i steblah roslyn agrusu (Grossularia reclinata (L.) Mill.) u zv'yazku z produktyvnistyu kultury [The effect of gibberellin and retardants on the redistribution of carbohydrates and nutrients in gooseberry (Grossularia reclinata (L.) Mill.) leaves and stems in relation to the culture productivity]. Fiziologia Rastenij i Genetika, 52(1), 31-45 (in Ukrainian).

Lau, T. S. L., Eno, E., Goldstein, G., Smith, C., \& Christopher, D. A. (2006). Ambient levels of UVB in Hawaii combined with nutrient deficiency decrease photosynthesis in near-isogenic maize lines varying in leaf flavonoids: Flavonoids decrease photoinhibition in plants exposed to UV-B. Photosynthetica, 44(3), 394403.

Makoveychuk, T. I., Mykhalska, L. M., \& Schwartau, V. V. (2018). Vplyv retardantiv - pohidnyh ciklogeksandioniv na produktyvnist pshenyci [Influence of retardants - derivatives of cyclohexandiones on the productivity of winter wheat]. Fiziologia Rastenij i Genetika, 50(6), 499-507 (in Ukrainian).
March, S. R., Martins, D., \& McElroy, J. S. (2013). Growth inhibitors in turfgrass. Planta Daninha, 31(3), 733-747.

Marschner, H. (1995). Mineral nutrition of higher plants. Academic Press, London.

Marschner, P. (2012). Marschner's mineral nutrition of higher plants. 3d ed. Academic Press.

Matysiak, K. (2006). Influence of trinexapac-ethyl on growth and development of winter wheat. Joumal of Plant Protection Research, 46(2), 133-143.

McCann, S. E., \& Huang, B. (2007). Effects of trinexapac-ethyl foliar application on creeping bentgrass responses to combined drought and heat stress. Crop Science, 47(5), 2121-2128.

McCullough, P. E., Liu, H., McCarty, L. B., Whitwell, T., \& Toler, J. E. (2006). Bermudagrass putting green growth, color, and nutrient partitioning influenced by nitrogen and trinexapac-ethyl. Crop Science, 46(4), 1515-1525.

McGrath, M. J., Koczan, J. M., Kennelly, M. M., \& Sundin, G. W. (2009). Evidence that prohexadione-calcium induces structural resistance to fire blight infection. Phytopathology, 99(5), 591-596.

Mirabella, N. E., Abbate, P. E., Alonso, M. P., Panelo, J., \& Pontaroli, A. C. (2019). Identifying traits at crop maturity and models for estimation of lodging susceptibility in bread wheat. Crop and Pasture Science, 70(2), 95.

Miroshnichenko, I. M., Makoveychuk, T. I., Mykhalska, L. M., \& Schwartau, V. V. (2017). Zminy elementnoho skladu roslyn pshenytsi ozymoyi za diyi Mehafolu ta petardantiv [Changes in the elemental composition of winter wheat plants caused by the action of Megafol and retardants]. Regulatory Mechanisms in Biosystems, 8(3), 403-409 (in Ukrainian).

Morgun, V. V., Sanin, Y. V., \& Schwartau, V. V. (2015). Klub 100 centneriv. Suchasni sorty ta optimal'ni sistemi zhivlennya j zahistu ozimoyi pshenyci [Club 100 centners. Modem varieties and optimal systems of nutrition and protection of winter wheat]. Logos, Kyiv (in Ukrainian).

Morgun, V. V., Schwartau, V. V., \& Kiriziy, D. A. (2010). Fiziologicheskiye osnovy formirovaniya vysokoj produktivnosti zernovyh zlakov [Physiological fundamentals of formation of high productivity in grain cereals ]. Fiziologia i Biochimija Kultumykh Rastenij, 42(5), 371-392 (in Russian).

Mykhalska, L. M., Makoveychuk, T. I., \& Schwartau, V. V. (2019). Zastosuvannya dobryva megafol ta retardantiv klasu atsyltsykloheksandioniv na posivakh pshenytsi ozymoyi [Application of fertilizer megafol and retardants of acylcyclohexadione class on winter wheat crops]. Fiziologia Rastenij i Genetika, 51(6), 549-551 (in Ukrainian).

Na, C.-I., Hamayun, M., Khan, A. L., Kim, Y.-H., Choi, K.-I., Kang, S.-M., Kim, S.I., Kim, J.-T., Won, J.-G., \& Lee, I.-J. (2011). Influence of prohexadione-calcium, trinexapac-ethyl and hexaconazole on lodging characteristic and gibberellin biosynthesis of rice (Oryza sativa L.). African Journal of Biotechnology, 10(61), 13097-13106.

Nangle, E. J., Gardner. D. S., Metzger, J. D., Street, J. R., \& Danneberger, T. K. (2012). Impact of nitrogen source and trinexapac-ethyl application on creeping bentgrass (Agrostis stolonifera L.) physiology under neutral shade, deciduous tree shade, and full sunlit conditions. Journal of the American Society for Horticultural Science, 47(7), 936-942.

O’Neill, D. P., \& Ross, J. J. (2002). Auxin regulation of the gibberellin pathway in pea. Plant Physiology, 130(4), 1974-1982.

Okuno, A., Hirano, K., Asano, K., Takase, W., Masuda, R., Morinaka, Y., UeguchiTanaka, M., Kitano, H., \& Matsuoka, M. (2014). New approach to increasing rice lodging resistance and biomass yield through the use of high gibberellin producing varieties. PLoS One, 9(2), e86870.

Pal, M., Rao, L. S., Jain, V., Srivastava, A. C., Pandey, R., Raj, A., \& Singh, K. P. (2005). Effect of elevated $\mathrm{CO}_{2}$ and nitrogen on wheat growth and photosynthesis. Biologia Plantarum, 49(3), 467-470.

Pask, A. J. D., Pietragalla, J., Mullan, D. M., \& Reynolds, M. P. (Eds.). (2012). Physiological breeding II: A field guide to wheat phenotyping. Cimmyt, Mexico.

Paulson, G. S., Hull, L. A., \& Biddinger, D. J. (2005). Effect of a plant growth regulator prohexadione-calcium on insect pests of apple and pear. Journal of Economic Entomology, 98(2), 423-431.

Piñera-Chavez, F. J., Berry, P. M., Foulkes, M. J., Jesson, M. A., \& Reynolds, M. P. (2016). Avoiding lodging in irrigated spring wheat. I. Stem and root structural requirements. Field Crops Research, 196, 325-336.

Piñera-Chavez, F. J., Berry, P. M., Foulkes, M. J., Molero, G., \& Reynolds, M. P. (2016). Avoiding lodging in irrigated spring wheat. II. Genetic variation of stem and root structural properties. Field Crops Research, 196, 64-74.

Piñera-Chavez, F. J., Reynolds, M., Berry, P. M., Foulkes, M. J., \& Molero, G. (2020). Optimizing phenotyping methods to evaluate lodging risk for wheat. Field Crops Research, 258(1), 107933.

Pinheiro, M. G., Souza, C. A., Junior, J. F. C. C., da Silva, E. R., \& Kandler, R. (2018). Prohexadione-calcium and nitrogen topdressing fertilisation on productive performance of maize with late sowing. International Journal of Plant and Soil Science, 25(4), 1-10.

Pornaro, C., Fiorio, S., Macolino, S., \& Richardson, M. D. (2017). Growth and quality responses of low-maintenance turfgrasses to trinexapac-ethyl. Crop Protection, $98,236-242$. 
Pricinotto, L. F., Zucareli, C., Fonseca, I. C. B., Oliveira, M. A., Ferreira, A. S., \& Spolaor, L. T. (2015). Trinexapac-ethyl in the vegetative and reproductive performance of com. African Journal of Agricultural Research, 10(14), 1735-1742.

Puhl, F., Stadler, F., \& Treutter, D. (2008). Alterations of flavonoid biosynthesis in young grapevine (Vitis vinifera L.) leaves, flowers, and berries induced by the dioxygenase inhibitor prohexadione-Ca. Journal of Agricultural and Food Chemistry, 56(7), 2498-2504.

Qian, Y. L., \& Engelke, M. C. (1999). Influence of trinexapac-ethyl on diamond zoysiagrass in a shaded environment. Crop Science, 39(1), 202-208.

Rademacher, W. (2000). Growth retardants: Effects on gibberellin biosynthesis and other metabolic pathways. Annual Review of Plant Physiology and Plant Molecular Biology, 51(1), 501-531.

Rademacher, W. (2014). Prohexadione-Ca and trinexapac-ethyl: Similarities in structure but differences in biological action. Acta Horticulturae: XII International Symposium on Plant Bioregulators in Fruit Production, 1042, 33-41.

Rademacher, W. (2016). Chemical regulators of gibberellin status and their application in plant production. Annual Plant Reviews, 49, 359-403.

Rademacher, W., Temple-Smith, K. E., Griggs, D. L., \& Hedden, P. (1992). The mode of action of acyl cyclo-hexanedione - a new type of growth retardant. In: Karssen, C. M., van Loon, L. C., \& Vreugdenhil, D. (Eds.). Progress in plant growth regulation. Proceedings of the 14th International Conference on Plant Growth Substances. Kluwer Academic Publishers, Dordrecht. Pp. 571-577.

Reynolds, M. P., Pask, A. J. D., \& Mullan, D. M. (Eds.). (2012). Physiological breeding I: Interdisciplinary approaches to improve crop adaptation. Cimmyt, Mexico.

Reynolds, M., Foulkes, J., Furbank, R., Griffiths, S., King, J.,Murchie, E., Parry, M., \& Slafer, G. (2012). Achieving yield gains in wheat. Plant, Cell \& Environment, $35,1799-1823$

Rolston, P., Trethewey, J., Chynoweth, R., \& McCloy, B. (2010). Trinexapac-ethyl delays lodging and increases seed yield in perennial ryegrass seed crops. New Zealand Journal of Agricultural Research, 53(4), 403-406.

Rose, N. R., Woon, E. C., Tumber, A., Walport, L. J., Chowdhury, R., Li, X. S. King, O. N., Lejeune, C., Ng, S. S., Krojer, T., Chan, M. C., Rydzik, A. M., Hopkinson, R. J., Che, K. H., Daniel, M., Strain-Damerell, C., Gileadi, C., Kochan, G., Leung, I. K., Dunford, J., Yeoh, K. K., Ratcliffe, P. J., Burgess-Brown, N., von Delft, F., Muller, S., Marsden, B., Brennan, P. E., McDonough, M. A. Oppermann, U., Klose, R. J., Schofield, C. J., \& Kawamura, A. (2012). Plant growth regulator daminozide is a selective inhibitor of human $\mathrm{KDM} 2 / 7$ histone demethylases. Journal of Medicinal Chemistry, 55(14), 6639-6643.

Ross J. J., O'Neill, D. P., Smith, J. J., Kerckhoffs, L. H., \& Elliott, R. C. (2000). Evidence that auxin promotes gibberellin A1 biosynthesis in pea. Plant Journal, 21(6), 547-552.

Ross, J., \& O’Neill, D. (2001). New interactions between classical plant hormones. Trends Plant Science, 6(1), 2-4.

Sakamoto, T., Miura, K., Itoh, H., Tatsumi, T., \& Ueguchi-Tanaka, M. (2004) An overview of gibberellin metabolism enzyme genes and their related mutants in rice. Plant Physiology, 134(4), 1642-1653.

Sakr, W. R. A. (2009). Response of paspalum turfgrass grown in sandy soil to trinexapac-ethyl and irrigation water salinity. International Journal of Horticultural Science and Ornamental Plants, 1(2), 15-26.

Sameri, M., Nakamura, S., Nair, S. K., Takeda, K., \& Komatsuda, T. (2009). A quantitative trait locus for reduced culm internode length in barley segregates as a Mendelian gene. Theoretical and Applied Genetics, 118, 643-652.

Sang-Kuk, K., \& Hak-Yoon, K. (2014). Effects of gibberellin biosynthetic inhibitors on oil, secoisolaresonolodiglucoside, seed yield and endogenous gibberellin content in flax. Korean Journal of Plant Resources, 27(3), 229-235.

Sattar, A., Cheema, M. A., Sher, A., Abbas, T., Ijaz, M., Ul-Allah, S., Butt, M., Qayyum, A., \& Hussain, M. (2019). Exogenously applied trinexapac-ethyl improves photosynthetic pigments, water relations, osmoregulation and antioxidants defense mechanism in wheat under salt stress. Cereal Research Communications, 47(3), 430-441.

Shah, L., Yahya, M., Shah, S., Nadeem, M., Ali, A., Ali, A., Wang, J., Riaz, M. W Rehman, S., Wu, W., Khan, R. M., Abbas, A., Riaz, A., Anis, G. B., Si, H., Jiang, H., \& Ma, C. (2019). Improving lodging resistance: Using wheat and rice as classical examples. International Journal of Molecular Sciences, 20(17), 4211.

Sheikh Mohammadi, M. H., Etemadi, N., Arab, M. M., Aalifar, M., Arab, M., \& Pessarakli, M. (2016). Molecular and physiological responses of Iranian perennial ryegrass as affected by trinexapac ethyl, paclobutrazol and abscisic acid under drought stress. Plant Physiology and Biochemistry, 111, 129-143.

Shekoofa, A., \& Emam, Y. (2008). Effects of nitrogen fertilization and plant growth regulators (PGRs) on yield of wheat (Triticum aestivum L.) cv. Shiraz. Journal of Agricultural Science and Technology, 10(2), 101-108.
Simmons, D. B., Grey, T. L., Faircloth, W., Vencill1, W. K., \& Webster, T. M. (2017). Trinexapac-ethyl winter wheat (Triticum aestivum L.) cultivar evaluations with variable rates of nitrogen. Journal of Experimental Agriculture International, 16(5), 1-9.

Srivastava, L. M. (2003). Plant growth and development. Hormones and the environment. Annals of Botany, 92(6), 846

Steinke, K., \& Stier, J. (2003). Nitrogen selection and growth regulator applications for improving shaded turf performance. Crop Science, 43(4), 1399-1406.

Schwartau, V. V., Mykhalska, L. M., \& Makoveychuk, T. I. (2018). Vmist mikroelementiv u roslynakh pshenytsi ozymoyi za diyi retardantiv [The content of microelements in winter wheat plants at retardant action]. Fiziologia Rastenij i Genetika, 50(6), 474- 483 (in Ukrainian).

Tanimoto, E. (2005). Regulation of root growth by plant hormones-roles for auxin and gibberellin. Journal Critical Reviews in Plant Sciences, 24(4), 249-265.

Trethewey, J. A. K., Rolston, M. P., McCloy, B. L., \& Chynoweth, R. J. (2016). The plant growth regulator, trinexapac-ethyl, increases seed yield in annual ryegrass (Lolium multiflorum Lam.). New Zealand Joumal of Agricultural Research, 59(2), 113-121.

Turner, J. A. (Ed.). (2018). The pesticide manual: A world compendium. BCPC Publications, Hampshire

Vavilala, D. T., Reddy, S., Sachchidanand, Prakash, S., Ponnaluri, V. K. C., Kumar, A., \& Mukherji, M. (2014). Prohexadione, a plant growth regulator, inhibits histone lysine demethylases and modulates epigenetics. Toxicology Reports, 1 , $1152-1161$.

Virych, P. A., Makoveychuk, T. I., \& Schwartau, V. V. (2012). Vplyv trineksapaketylu na vmist anioniv u roslynah Hordeum vulgare L. [Influence of trinexapacethyl on content of anions in plants of Hordeum vulgare L.]. Uchenyye Zapiski Tavricheskogo Natsional'nogo Universiteta im. V. I. Vernadskogo, Biologiya, Khimiya, 25(3), 27-30 (in Ukrainian).

Wang, D., Ding, W. H., Feng, S. W., Hu, T. Z., Li, G., Li, X. H., Yang, Y. Y., \& Ru, Z. G. (2016). Stem characteristics of different wheat varieties and its relationship with lodging-resistance. Ying Yong Sheng Tai Xue Bao = The Journal of Applied Ecology, 27, 1496-1502.

Wiecko, G., \& Couillard, A.-A. (1997). Response of 'tifway' bermudagrass to trinexapac-ethyl and chelated iron. Journal of Turfgrass Management, 2(3), 15-21.

Wiersma, J. J., Dai, J., \& Durgan, B. R. (2011). Optimum timing and rate of TE to reduce lodging in spring wheat. Agronomy Journal, 103, 864-870.

Xiao, Y., Liu, J., Li, H., Cao, X., Xia, X., \& He, Z. (2015). Lodging resistance and yield potential of winter wheat: effect of planting density and genotype. Frontiers of Agricultural Science and Engineering, 2(2), 168-178.

Xiao-Ying, W., Tian-Ming, H. U., Quan-Zhen, W., Li-Min, T., Xiao-Ling, Z., \& Kai, T. (2009). Growth of Kentucky bluegrass as influenced by nitrogen and trinexapac-ethyl. Agricultural Sciences, 8(12), 1498-1502.

Xu, C., \& Huang, B. (2011). Proteins and metabolites regulated by trinexapac-ethy in relation to drought tolerance in Kentucky bluegrass. Journal of Plant Growth Regulation, 31, 25-37.

Xu, C., Gao, Y., Tian, B., Ren, J., Meng, Q., \& Wang, P. (2017). Effects of EDAH, a novel plant growth regulator, on mechanical strength, stalk vascular bundles and grain yield of summer maize at high densities. Field Crops Research, 200, 71-79.

Yang, L., Yang, D., Yan, X., Cui, L., Wang, Z., \& Yuan, H. (2016). The role of gibberellins in improving the resistance of tebuconazole-coated maize seeds to chilling stress by microencapsulation. Scientific Reports, 6, 35447 .

Zagonel, J., \& Fernandes, E. C. (2007). Rates and application times of growth reducer affecting wheat cultivars at two nitrogen rates. Planta Daninha, 25(2), 331-339.

Zagonel, J., Venancio, W. S., \& Kunz, R. P. (2002). Effect of growth regulator on wheat crop under different nitrogen rates and plant densities. Planta Daninha, 20(3), 471-476.

Zapiola, M. L., Chastain, T. G., Garbacik, C. J., Silberstein, T. B., \& Young, W. C. (2006). Trinexapac-ethyl and open field burning maximize seed yield in creeping red fescue. Agronomy Journal, 98(6), 1427-1434.

Zhang, M., Wang, H., Yi, Y., Ding, J., Zhu, M., Li, C., Guo, W., Feng, C., \& Zhu, X. (2017b). Effect of nitrogen levels and nitrogen ratios on lodging resistance and yield potential of winter wheat (Triticum aestivum L.). PLoS One, 12(11), e0187543.

Zhang, Y. X, Su, S., Tabori, M., Yu, J., Chabot, D., Baninasab, B., Wang, X., Ma, B.-L., Li, C., \& Khanizadeh, S. (2017a). Effect of selected plant growth regulators on yield and stem height of spring wheat in Ontario. Journal of Agricultural Science, $9(12), 30-42$. 